Old Dominion University

ODU Digital Commons

OEAS Faculty Publications

Ocean, Earth \& Atmospheric Sciences

$7-1995$

\title{
Trophic Transfer of Fatty Acids, Sterols, and a Triterpenoid Alcohol Between Bacteria, a Ciliate, and the Copepod Acartia Tonsa
}

Melissa C. Ederington

George B. McManus

H. Rodger Harvey

Old Dominion University, rharvey@odu.edu

Follow this and additional works at: https://digitalcommons.odu.edu/oeas_fac_pubs

Part of the Biochemistry Commons, Developmental Biology Commons, Ecology and Evolutionary Biology Commons, Environmental Sciences Commons, and the Marine Biology Commons

\section{Repository Citation}

Ederington, Melissa C.; McManus, George B.; and Harvey, H. Rodger, "Trophic Transfer of Fatty Acids, Sterols, and a Triterpenoid Alcohol Between Bacteria, a Ciliate, and the Copepod Acartia Tonsa" (1995). OEAS Faculty Publications. 157.

https://digitalcommons.odu.edu/oeas_fac_pubs/157

\section{Original Publication Citation}

derington, M.C., McManus, G.B., \& Harvey, H.R. (1995). Trophic transfer of fatty acids, sterols, and a triterpenoid alcohol between bacteria, a ciliate, and the copepod Acartia tonsa. Limnology and Oceanography, 40(5), 860-867. doi: 10.4319/lo.1995.40.5.0860

This Article is brought to you for free and open access by the Ocean, Earth \& Atmospheric Sciences at ODU Digital Commons. It has been accepted for inclusion in OEAS Faculty Publications by an authorized administrator of ODU Digital Commons. For more information, please contact digitalcommons@odu.edu. 


\title{
Trophic transfer of fatty acids, sterols, and a triterpenoid alcohol between bacteria, a ciliate, and the copepod Acartia tonsa
}

\author{
Melissa C. Ederington
}

Chesapeake Biological Laboratory, University of Maryland Center for Environmental and Estuarine Studies, P.O.B. 38, Solomons 20688

\section{George B. McManus}

Marine Environmental Sciences Consortium, Dauphin Island Sea Lab, Dauphin Island, Alabama 36528 and Department of Marine Sciences, University of South Alabama, Mobile 36688

\section{H. Rodger Harvey ${ }^{1}$}

Chesapeake Biological Laboratory, University of Maryland Center for Environmental and Estuarine Studies

\begin{abstract}
The incorporation of lipids into the copepod Acartia tonsa and its eggs was measured when it was fed either a bacterivorous ciliate (Pleuronema sp.) or a diatom (Thalassiosira weissflogii). Egg production was 10-fold higher on the diatom diet, whereas hatch success of eggs was the same for algal and ciliate diets. Adult copepods fed diatoms contained more total fatty acid and sterols than copepods fed the ciliate diet, and individual lipids reflected the dietary source. Eggs from diatom-fed copepods had fewer fatty acids but more sterols than eggs from copepods on a ciliate diet. Ciliate-fed copepods and their eggs contained significant amounts of odd chain-length and branched fatty acids diagnostic of bacteria. These fatty acids, in particular the iso $\mathrm{C}_{15}$ and $\mathrm{C}_{17}$, were also elevated in ciliates feeding on bacteria in culture, suggesting the direct transfer of bacterial fatty acids from ciliates to copepods and their eggs. We also observed the assimilation of tetrahymanol, a triterpenoid alcohol specific to ciliates, into adults and eggs when copepods were fed a ciliate diet. Tetrahymanol accounted for $6.6 \pm 1.9 \%$ of total neutral lipids in adults and $35.4 \pm 6.5 \%$ in eggs. These results suggest that bacterivorous ciliates may not provide copepods with adequate nutritional requirements for long-term survival, but that lipids unique to bacteria and ciliates can be assimilated by and may provide useful tracers of consumption by copepods.
\end{abstract}

Ciliated protozoa are important in the utilization of bacterial as well as phytoplankton production in estuarine and coastal marine systems (e.g. Capriulo and Carpenter 1983; Sherr and Sherr 1987; Gifford 1988). Bacteria are too small to be grazed efficiently by metazoans, and planktonic ciliates provide a mechanism by which bacterial production may enter higher trophic levels (see Stoecker and Capuzzo 1990; Gifford 1991; Sanders and Wickham 1993). Acartia tonsa, the dominant copepod in estuarine and coastal waters, has been shown to feed on scuticociliates-small bacterivorous protists abundant in detri-

\footnotetext{
1 Corresponding author.
}

Acknowledgments

We thank Alan Foster for assistance with copepod collections and TLC-FID analyses. H. Millsaps provided the original Thalassiosira weissflogii culture, and E. Lessard provided the original Pleuronema sp. isolate, which was identified by J. Sniezek. Comments by three anonymous reviewers substantially improved the final manuscript.

This research was supported by the National Science Foundation (grants OCE 90-12553, OCE 92-03478, and OSR 9108761).

Contribution 2608 of the Center for Environmental and Estuarine Studies of the University of Maryland System. tus-rich environments (Sherr et al. 1986) -and can remove up to $200 \%$ of their standing crop per day (Dolan 1991). A. tonsa also eats phytoplankton, detritus, its own eggs and nauplii, and other ciliates, but does not consume bacteria in significant quantities (Lonsdale 1979; Roman 1984). Thus, if these copepods are to obtain detritusbased bacterial production, it must be through the ingestion of heterotrophic nanoflagellates, bacterivorous ciliates, or detrital particles. Among these potential pathways, the existence of a trophic link between copepods and ciliates has been well established (see Pierce and Turner 1992).

$A$. tonsa does not store appreciable amounts of lipid because it does not synthesize wax esters or produce a discrete oil droplet (Sargent and Falk-Petersen 1988). Tester and Turner (1990) demonstrated that carbon ingested by adult females appears rapidly in eggs $(<10 \mathrm{~h})$, making it possible to observe changes in the biochemical composition of eggs as well as adults during short-term laboratory experiments. To our knowledge, the detailed lipid composition of $A$. tons $a$ and its eggs produced under different dietary regimes has not been previously reported.

In this paper, we address the transfer of lipids found principally in bacteria and ciliates to copepods in controlled grazing experiments. We examine the lipid dis- 
tribution of a diatom and a bacterivorous ciliate as food sources, comparing them to the lipids of field-caught copepods, copepods fed on either diatoms or ciliates, and eggs produced on each diet. Whereas bacterivory by ciliates and other protists has been measured in several studies (c.g. Hollibaugh et al. 1980; Wikner et al. 1986; Sherr et al. 1987), we investigated lipids as potential markers of trophic exchange by using lipids specific to bacteria and ciliates. Our results suggest that bacterivorous ciliates are of limited nutritional benefit to copepods but that specific lipids may prove useful as food-web tracers of bacterial and ciliate ingestion.

\section{Methods}

Cultures-The ciliate, Pleuronema sp., was cultured in $0.45-\mu \mathrm{m}$-filtered seawater enriched with $0.005 \%$ yeast extract to stimulate growth of the mixed assemblage of bacteria present in the culture. This small scuticociliate averaged $15.0 \pm 1.4 \mu \mathrm{m}$ in equivalent spherical diameter (ESD). The diatom, Thalassiosira weissflogii (clone CCMP 1336), was cultured in $\mathrm{f} / 2$ medium at $12 \mathrm{psu}$ at $19^{\circ} \mathrm{C}$ in continuous light. At harvest, cells were $15.0 \pm 1.5 \mu \mathrm{m}$ in ESD.

Pleuronema sp. was harvested by centrifuging twice and rinsing in filtered seawater $(5,000 \mathrm{rpm}$ for $30 \mathrm{~min}$ in a refrigerated IEC centrifuge) to separate the cells from spent medium and bacteria. Both diets were diluted to $\sim 1.8 \times 10^{3}$ cells $\mathrm{m}^{-1}$ for the feeding experiment. Subsamples of both food types were also collected on glassfiber filters (Whatman $\mathrm{GF} / \mathrm{F}$ ) and frozen at $-20^{\circ} \mathrm{C}$ for lipid analysis. All filters were combusted at $450^{\circ} \mathrm{C}$ for 2 $\mathrm{h}$ before use.

Feeding experiment $-A$. tonsa was collected from surface waters of Mobile Bay, Alabama, with a 64- $\mu \mathrm{m}-\mathrm{mesh}$ plankton tow. For the experiment, 1,600 females were sorted individually and placed in $12 \mathrm{psu} 0.45-\mu \mathrm{m}$-filtered seawater for a minimum of $2 \mathrm{~h}$ to clear their guts. Of these females, 250 were then collected on a glass-fiber filter and frozen to determine initial lipid content of the copepods. The remaining 1,350 females were divided into batches of 150 and placed in one of nine 1-liter plastic beakers. This population density is about twofold greater than that attained by Acartia species in Chesapeake Bay (copepodite stages only, White and Roman 1992). A total of three treatments was used, with three replicates per treatment: a control with no food, the diatom as sole food, and the ciliate as sole food. Within each beaker, copepods were kept in sleeves fitted with $202-\mu \mathrm{m}$ screens to separate adults from eggs produced during each incubation. The beakers were kept in an incubator at $19^{\circ} \mathrm{C}$ on a $14: 10$ L/D cycle throughout the experimental period (96 h). During the first $24 \mathrm{~h}$ of the experiment, ciliates and diatoms were subsampled, preserved in Lugol's iodine solution, and counted to estimate clearance rates. Clearance rates were calculated as described by Frost (1972), assuming no growth of ciliates or diatoms over the interval between samplings. Calculated clearance rates can thus be considered conservative. The inner sleeves containing copepods were transferred daily to fresh beakers of fresh food. The remaining seawater was poured through a 64$\mu \mathrm{m}-\mathrm{mesh}$ screen to collect eggs. Eggs were counted and filtered onto a glass-fiber filter and frozen at $-20^{\circ} \mathrm{C}$. Within cach replicate, daily egg harvests were pooled for lipid analysis.

Starved animals in control beakers were collected after $72 \mathrm{~h}$ onto a filter and frozen until analysis. Copepods fed either the ciliate or diatom diet were allowed to feed until $96 \mathrm{~h}$ and collected similarly. At the end of the experiment, 25 eggs were removed from each beaker containing fed copepods and incubated at $19^{\circ} \mathrm{C}$ for $24 \mathrm{~h}$ to estimate hatch success. Hatch success was determined for each dietary treatment by counting unhatched eggs. Because of low egg production for starved copepods, all eggs from days 2 and 3 for each replicate were pooled prior to examination for hatch success.

Lipid analysis-Lipids were extracted from diets, copepods, and eggs three times using dichloromethane: methanol $(1: 1)$ with probe sonication as previously described by Harvey et al. (1987). Before use, all glassware was washed with detergent (Pierce RBS-35), acid washed with $15 \% \mathrm{HCl}$, and rinsed with dichloromethane : methanol $(1: 1)$. For all samples, the total lipid extract was first dried by rotary evaporation, redissolved in a smaller volume of solvent, and split into subsamples. Half of each sample was used to measure triacylglycerols. The remainder was used for individual component analysis after hydrolysis.

Triacylglycerols were determined by thin-layer chromatography with flame-ionization detection (TLC-FID) on an Iatroscan MK-V analyzer (e.g. Volkman et al. 1986). Aliquots $(10 \mu \mathrm{l})$ were spotted onto S-III Chromarods and developed in hexane : diethyl ether : formic acid $(85: 15$ : 0.2 ) for separation of major lipid classes. Peak areas were determined with a dedicated software package (TSCAN, RSS Inc.) and converted to concentrations from calibration curves using triolein.

For individual component analysis, internal standards ( $5 \alpha$-cholestane for neutral and nonadecanoic acid for fatty acids) were added to the remaining half of the lipid extract, and the fraction was subjected to mild alkaline hydrolysis using $0.2 \mathrm{~N}$ methanolic $\mathrm{KOH}$ with gentle heating $\left(70^{\circ} \mathrm{C}, 1 \mathrm{~h}\right)$. After cooling and addition of water, neutral lipids were partitioned into hexane: diethyl ether $(9: 1)$. The neutral fraction was dried under nitrogen and converted to respective trimethylsilyl ethers with $30 \mu \mathrm{l}$ of bis(trimethylsilyl)trifluoroacetamide (BSTFA) amended with $25 \%$ pyridine (ten Haven et al. 1989). Fatty acids were partitioned following acidification to $\mathrm{pH} 2$ and converted to the fatty acid methyl esters (FAMES) with $\mathrm{BF}_{3}$ in methanol $\left(70^{\circ} \mathrm{C}, 1 \mathrm{~h}\right)$. FAMES were purified by partitioning into hexane : diethyl ether $(9: 1)$.

Both neutral and polar (fatty acid) fractions were quantified by capillary gas chromatography (GC) with a Hewlett-Packard 5890A instrument with flame ionization detection. Scparations were performed with a (5\%-phenyl)- 
Table 1. Egg production and hatch success of Acartia tonsa starved or fed a ciliate or diatom diet. Standard errors of triplicate samples are given in parentheses.

\begin{tabular}{|c|c|c|c|}
\hline & Starved & Ciliate & Diatom \\
\hline Size of food $(\mu \mathrm{m})$ & - & $15(1.7)$ & $15(1.4)$ \\
\hline Food concn $\left(\times 10^{3}\right.$ cells $\left.\mathrm{ml}^{-1}\right)$ & - & $1.7(0.17)$ & $1.9(0.20)$ \\
\hline Clearance rate* $\left(\mathrm{ml} \mathrm{copepod}{ }^{-1} \mathrm{~d}^{-1}\right)$ & - & $2.6(0.24)$ & $1.7(0.24)$ \\
\hline Egg production (eggs copepod ${ }^{-1} \mathrm{~d}^{-1}$ ) & $1(0.2)$ & $5(0.5)$ & $48(11.9)$ \\
\hline Hatch success ( $\%$ hatched) & $42(2)$ & $95(2)$ & $95(3)$ \\
\hline
\end{tabular}

* Measured during first $24 \mathrm{~h}$ of the experiment.

methyl silicone-fused capillary column (DB-5, $30 \mathrm{~m}$ long, $0.32-\mathrm{mm}$ i.d., $0.25-\mu \mathrm{m}$ film thickness) with hydrogen as the carrier gas (e.g. Harvey and McManus 1991). For the polar fraction, the temperature program was $50^{\circ} \mathrm{C}$ to $120^{\circ} \mathrm{C}$ at a rate of $10^{\circ} \mathrm{C} \mathrm{min}{ }^{-1}$ followed by $4^{\circ} \mathrm{C} \mathrm{min}-1$ to $300^{\circ} \mathrm{C}$. The temperature program for the sterol fraction was similar, except for the addition of a 19-min isothermal hold at $300^{\circ} \mathrm{C}$. Chromatographic data were collected with a dedicated data system (Chemstation-Hewlett-Packard) and quantified by comparison of peak areas with the internal standard.

Structural identifications were performed with two instruments: electron impact (EI) mass spectra were obtained by interfacing an identical capillary GC with a Hewlett-Packard 5970B mass-selective detector operating at $70 \mathrm{eV}$ with acquisition over the 50-600-amu range. Confirmation of molecular mass assignments obtained in the EI mode was made by chemical ionization GC/MS with a HP 5889A instrument and $\mathrm{CH}_{4}$ as the reagent gas (1.7 torr). Conditions similar to GC were used for both instruments, except that helium was the carrier gas and a $0.2-\mathrm{mm}$-i.d. column was used.

\section{Results}

A. tons $a$ cleared both algal and ciliate diets at similar rates during the first $24 \mathrm{~h}$ of the experiment (Table 1). Previous experiments have shown that the ciliates are cleared at rates comparable to those for similar-sized phytoplankton (McManus and Harvey unpubl. results), and observed clearance rates were comparable to those for $A$. tonsa in field and laboratory experiments (Berggreen et al. 1988; Dolan 1991). Although egg production on the diatom diet was almost 10 -fold higher than on the ciliate dict, hatch success was similar for copepods regardless of food source, with $95 \%$ of the eggs hatched for both treatments (Table 1). As expected, the absence of food inhibited egg production in starved copepods with only 1 egg copepod ${ }^{-1} \mathrm{~d}^{-1}$ produced and substantially lowered hatch success (Table 1 ).

Lipid content of experimental diets - The ciliate and diatom differed in amount and distribution of fatty acids (Table 2). T. weissflogii had a fatty acid distribution common for this genus, with relatively high proportions of the fatty acids 16:0,16:1(9), and 20:5 (Volkman et al. 1989; Dunstan et al. 1994). The principal fatty acids observed for this culture of $T$. weissflogii were $16: 1(9), 16$ :
$0,20: 5$, and $14: 0$ (Table 2). Small amounts (3.4\%) of fatty acids generally attributed to bacteria (branched and odd chain length) were also present in the diatom due to small numbers of bacteria in the cultures, which were not axenic.

Branched chain fatty acids, in particular iso and anteiso forms of the odd chain length 15:0 and 17:0 acids, are generally considered unique components of bacteria (Kaneda 1991). These fatty acids arc often found in areas of high bacterial activity (e.g. Canuel and Martens 1992) and have been previously used as specific markers of bacteria in sediments (Johns et al. 1977; Perry et al. 1979). Pleuronema sp., used as the ciliate food treatment, containcd substantial quantities of bacterial fatty acids, accounting for $14.6 \%$ of total ciliate fatty acids. The iso 15 : 0 was present in highest individual concentration at $6.3 \%$ (Table 2). The appearance of these fatty acids in Pleuronema $\mathrm{sp}$. fed a solely bacterial diet strongly suggests their direct incorporation from the ingestion of bacteria.

A sterol distribution typical of diatoms was observed in $T$. weissflogii, with 24-methylcholesta-5,24(28)-dien$3 \beta$-ol as the dominant sterol (Table 3). Other sterols present included 24-ethylcholesta-5,22-dien-3 $\beta$-ol, 24-ethylcholesta-5,24(28)-dien-3 $\beta$-ol, 24-methylcholesta-5,22dien-3 $\beta$-ol, and traces of 24 -methylcholest-5-en-3 $\beta$-ol. Although several of these sterols are also found in other phytoplankton, the presence of 24-methylcholesta$5,24(28)$-dien-3 $\beta$-ol is frequently used as a molecular marker for the contribution of diatom-derived organic matter (Nichols et al. 1983; Volkman 1986). This $C_{28}$ sterol has also been observed in two dinoflagellates and two members of the Prasinophyceae, but it is ubiquitous in diatoms (Volkman 1986).

In contrast to the distribution of sterols in the diatom, Pleuronema sp. contained a single triterpenoid alcohol, tetrahymanol (gammaceran-3 $\beta$-ol), as the dominant neutral lipid with only traces of sterols present (Table 3 ). Tetrahymanol is synthesized by a number of marine scuticociliates, including Pleuronema sp. (Harvey and McManus 1991), and appears to be produced de novo since it was not observed in their bacterial diet.

Fatty acid content of copepods and eggs $-A$. tonsa collected in Mobile Bay contained $16: 0$ as its dominant fatty acid, with significant concentrations of $18: 1(9)$ and 18 : 0 also present (Table 2). Saturated fatty acids, including $14: 0,16: 0$, and 18:0, are typical of calanoid copepods (Prahl et al. 1984; Harvey et al. 1987; Sargent and Falk- 
Table 2. Relative abundance (\%) of total fatty acids in animals, eggs, and experimental diets. Branched-chain fatty acids are indicated by $i$ (iso) and ai (anteiso).

\begin{tabular}{|c|c|c|c|c|c|c|c|c|}
\hline \multirow[b]{2}{*}{ Fatty acid } & \multirow[b]{2}{*}{ Diatom } & \multirow[b]{2}{*}{ Ciliate } & \multicolumn{4}{|c|}{ Copepods } & \multicolumn{2}{|c|}{ Eggs } \\
\hline & & & $\begin{array}{c}\text { Field } \\
\text { sample }\end{array}$ & Starved & $\begin{array}{l}\text { Diatom- } \\
\text { fed }\end{array}$ & $\begin{array}{l}\text { Ciliate- } \\
\text { fed }\end{array}$ & $\begin{array}{c}\text { Diatom } \\
\text { diet }\end{array}$ & $\begin{array}{c}\text { Ciliate } \\
\text { diet }\end{array}$ \\
\hline $12: 0$ & 0.0 & 0.9 & 0.0 & 0.0 & 0.0 & 0.0 & 0.0 & 0.0 \\
\hline$i 13: 0$ & 0.0 & 0.9 & 0.0 & 0.0 & 0.0 & 0.0 & 0.0 & 0.0 \\
\hline $13: 0$ & 0.0 & 0.4 & 0.0 & 0.0 & 0.0 & 0.0 & 0.0 & 0.0 \\
\hline$i 14: 0$ & 0.0 & 2.1 & 0.0 & 0.0 & 0.0 & 0.0 & 0.0 & 0.0 \\
\hline $14: 0$ & 8.0 & 4.1 & 3.8 & 0.6 & 4.4 & 1.0 & 2.5 & 0.0 \\
\hline$i 15: 0$ & 0.0 & 6.3 & 0.6 & 0.0 & 0.0 & 1.2 & 0.2 & 0.0 \\
\hline ai $15: 0$ & 0.5 & 1.6 & 0.5 & 0.0 & 0.0 & 0.0 & 0.2 & 0.0 \\
\hline $15: 0$ & 1.7 & 1.2 & 2.9 & 0.6 & 1.4 & 1.6 & 1.7 & 1.1 \\
\hline $16: 3(6,9,12)^{*}$ & 5.4 & 0.0 & 0.0 & 0.0 & 0.0 & 0.0 & 0.0 & 0.0 \\
\hline $16: 1(9)$ & 47.0 & 8.0 & 0.0 & 0.6 & 2.1 & 1.3 & 8.8 & 0.0 \\
\hline $16: 0$ & 22.0 & 4.2 & 45.7 & 43.2 & 43.1 & 26.5 & 37.7 & 30.0 \\
\hline$i 17: 0$ & 0.2 & 1.1 & 0.0 & 0.4 & 0.4 & 0.2 & 0.6 & 0.0 \\
\hline ai 17:0 & 0.1 & 0.4 & 0.0 & 0.3 & 0.0 & 0.4 & 0.2 & 0.0 \\
\hline $17: 0$ & 0.1 & 0.6 & 3.4 & 3.1 & 0.6 & 3.7 & 0.5 & 2.0 \\
\hline $18: 4(6,9,12,15)$ & 0.2 & 0.0 & 0.0 & 0.0 & 0.0 & 0.0 & 0.0 & 0.0 \\
\hline $18: 3(9,12,15)$ & 0.5 & 13.2 & 0.0 & 0.0 & 0.2 & 0.0 & 0.0 & 0.0 \\
\hline $18: 2(9,12)$ & 0.0 & 0.0 & 0.0 & 0.0 & 0.0 & 0.0 & 0.0 & 0.0 \\
\hline 18:1(9) & 0.9 & 5.3 & 10.4 & 0.0 & 0.6 & 0.0 & 5.0 & 0.0 \\
\hline $18: 1(11)$ & 1.4 & 34.6 & 4.9 & 11.2 & 2.2 & 22.5 & 2.9 & 11.5 \\
\hline $18: 0$ & 1.2 & 2.9 & 19.8 & 37.4 & 15.9 & 18.0 & 20.8 & 49.8 \\
\hline $20: 5(5,8,11,14,17)$ & 8.2 & 0.0 & 1.9 & 1.1 & 8.4 & 1.1 & 9.0 & 0.0 \\
\hline $20: 0$ & 1.3 & 8.9 & 0.9 & 0.8 & 13.7 & 5.8 & 1.2 & 0.0 \\
\hline $22: 1(13)$ & 1.8 & 1.8 & 5.3 & 0.0 & 7.0 & 6.9 & 8.7 & 2.1 \\
\hline $22: 0$ & 0.0 & 1.8 & 0.0 & 0.7 & 0.0 & 9.8 & 0.0 & 3.5 \\
\hline Total & 100.0 & 100.0 & 100.0 & 100.0 & 100.0 & 100.0 & 100.0 & 100.0 \\
\hline $\mathrm{ng}$ animal $^{-1}$ & - & - & 71.3 & 65.8 & 101.4 & 46.9 & 0.50 & 0.82 \\
\hline
\end{tabular}

* Designates position of each double bond from the terminal carboxyl group.

Petersen 1988). The polyunsaturated $20: 5$ acid was also observed and can be considered of likely dietary origin (Sargent and Falk-Petersen 1988; Harvey et al. 1987). Although the ability to synthesize fatty acids in copepods has not been examined, some freshwater zooplankton (cladocerans) do have the ability for de novo biosynthesis of fatty acids (Goulden and Place 1990). The rates of synthesis we observed, however, appear much below lipid requirements of animals that rely on dietary sources.

The fatty acid distribution of experimental animals var- ied according to diet (Table 2, Fig. 1). Starved copepods showed an increased proportion of saturated fatty acids, with $14: 0,16: 0,18: 0,20: 0$, and $22: 0$ accounting for $82.7 \%$ of total FAMES, and a concomitant reduction in polyunsaturated fatty acids (PUFA, Fig. 1). PUFAs remained low throughout, accounting for $1.9 \%$ of total fatty acids of copepods at time zero and $1.1 \%$ after $3 \mathrm{~d}$ of starvation.

Saturated fatty acids also accounted for the largest percentage of fatty acids in $T$. weissflogii-fed $A$. tonsa, in

Table 3. Relative abundance and concentration of sterols plus tetrahymanol in experimental diets, copepods, and eggs. Dash indicates sterols not present.

\begin{tabular}{|c|c|c|c|c|c|c|c|c|}
\hline \multirow[b]{2}{*}{ Compound } & \multirow[b]{2}{*}{$\begin{array}{c}\text { Diatom } \\
\text { diet }\end{array}$} & \multirow[b]{2}{*}{$\begin{array}{c}\text { Ciliate } \\
\text { diet }\end{array}$} & \multicolumn{4}{|c|}{ Copepods } & \multicolumn{2}{|c|}{ Eggs } \\
\hline & & & $\begin{array}{c}\text { Field } \\
\text { sample }\end{array}$ & Starved & $\begin{array}{l}\text { Diatom- } \\
\text { fed }\end{array}$ & $\begin{array}{l}\text { Ciliate- } \\
\text { fed }\end{array}$ & $\begin{array}{c}\text { Algal } \\
\text { diet }\end{array}$ & $\begin{array}{c}\text { Ciliate } \\
\text { diet }\end{array}$ \\
\hline Cholest-5-en- $3 \beta$-ol & - & - & 88.8 & 98.6 & 93.9 & 91.0 & 73.6 & 64.6 \\
\hline 24-methylcholesta-5,22-dien-3 $\beta$-ol & 3.5 & - & 2.4 & - & 1.1 & - & - & - \\
\hline 24-methylcholesta-5,24(28)-dien-3 $\beta$-ol & 78.6 & 1.1 & 3.4 & 1.4 & 2.2 & 1.9 & 15.2 & - \\
\hline 24-methylcholest-5-en-3 $\beta$-ol & 1.1 & - & 0.7 & - & - & - & - & - \\
\hline 24-ethylcholesta-5,22-dien-3 $\beta$-ol & 11.2 & - & 2.9 & - & 0.8 & 0.5 & 11.2 & - \\
\hline 24-ethylcholesta-5,24(28)-dien- $3 \beta$-ol & 5.7 & 0.5 & 1.7 & - & 2.0 & - & - & - \\
\hline Tetrahymanol & - & 98.4 & - & - & - & 6.6 & - & 35.4 \\
\hline Total & 100.0 & 100.0 & 100.0 & 100.0 & 100.0 & 100.0 & 100.0 & 100.0 \\
\hline ng animal ${ }^{-1}$ or egg & & & 20.4 & 8.1 & 18.1 & 12.0 & 0.18 & 0.11 \\
\hline
\end{tabular}




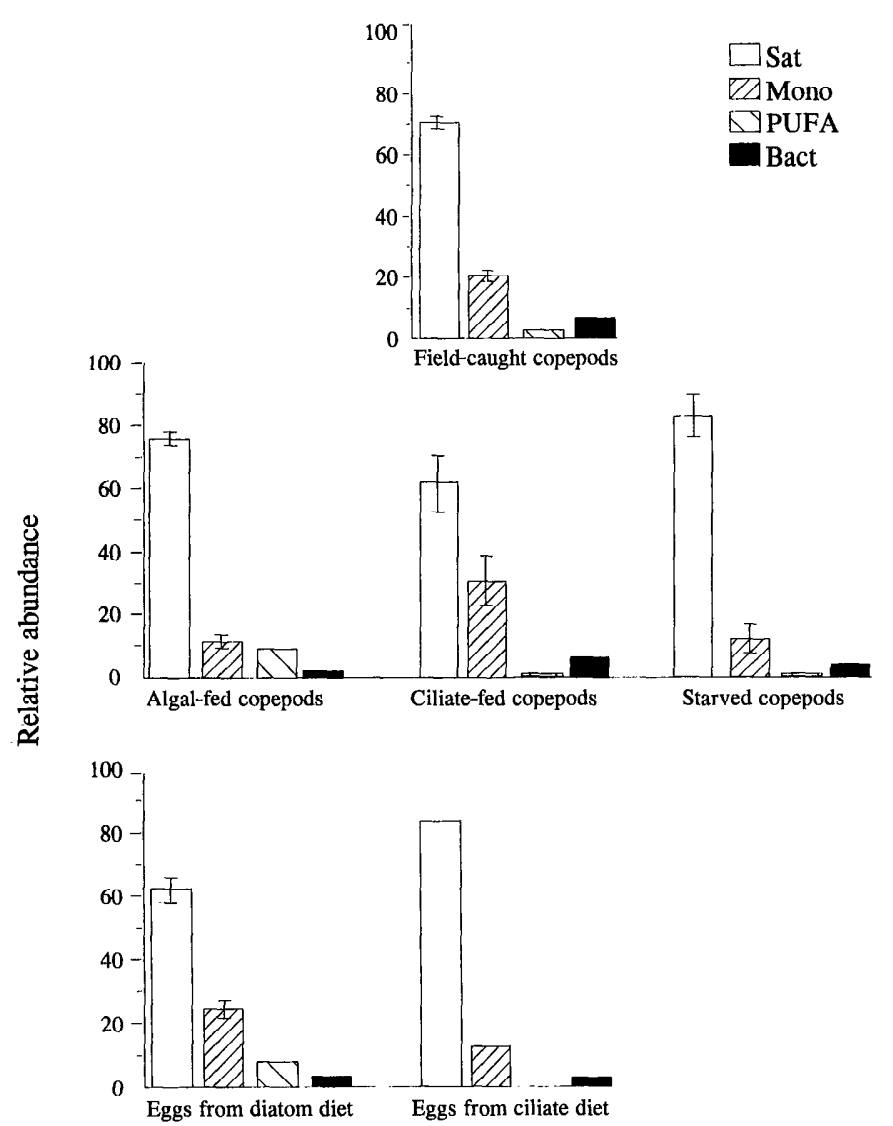

Fig. 1. Relative abundance of fatty acid classes for fieldcollected copepods, experimental copepods, and eggs produced for triplicate samples are shown. Abbreviations: Sat-saturated; Mono-monounsaturated; PUFA-polyunsaturated; Bactbacterial (odd-numbered chains and branched fatty acids). Error bars are shown only for samples with standard errors $>2.0 \%$ of the mean.

particular 16:0,18:0, and 20:0 (Fig. 1, Table 2). The polyunsaturated $20: 5$ acid was also elevated in diatomfed copepods. Fatty acids of bacterial origin accounted for $2.4 \%$ of total fatty acids in the animals and may be due to association with the algal food or possibly gut flora (Nott et al. 1985). In contrast, Pleuronema sp. provided a rich supply of bacterial fatty acids which subsequently appeared in copepods that consumed Pleuronema although the most abundant fatty acids of ciliate-fed copepods were typical of copepods $(16: 0,18: 1(11)$, and $18: 0$ ), bacterial fatty acids comprised $7.1 \%$ of total fatty acids (Fig. 1). These animals contained much higher amounts of bacterial fatty acids than did those fed the diatom diet, particularly $17: 0$ (3.7\% of total fatty acids).

Fatty acids in eggs produced during the experimental treatments varied depending on the food source of adult copepods. In general, eggs produced from copepods feeding on algae were lower in saturated acids and higher in monounsaturated, PUFAs, and bacterial acids than the adults which produced them (Fig. 1). Eggs of ciliate-fed copepods also varied in their fatty acid composition compared to the diets and adults. Large amounts of the two major fatty acids, $16: 0$ and $18: 0$, led to a much higher abundance of saturated fatty acids in eggs produced on the ciliate diet compared to those produced on the diatom diet (Fig. 1). Eggs produced on the diatom diet also reflected the contribution of algal polyunsaturated acids, principally $20: 5(9.0 \%)$. Although similar in relative abundance, the concentration of bacterial fatty acids was slightly higher in eggs produced from the ciliate diet (25 vs. $17 \mathrm{pg} \mathrm{egg}^{-1}$, Table 2).

Sterols and triterpenoid alcohols in copepods and their eggs-In diatom-fed copepods, cholest-5-en- $3 \beta$-ol (cholesterol) comprised $94 \%$ of the total sterols, with small amounts of 24-methylcholesta-5,24(28)-dien-3 $\beta$-ol, 24ethylcholesta-5,24(28)-dien-3 $\beta$-ol, 24-methylcholesta5,22 -dien-3 $\beta$-ol, and 24-ethylcholesta-5,22-dien-3 $\beta$-ol also present (Table 3 ). Field-collected copepods contained similar distributions, with the addition of 24-methylcholest-5-en-3 $\beta$-ol (Table 3). Starved animals showed reduced sterol levels, with cholesterol and 24-methylcholesta-5,24(28)-dien-3 $\beta$-ol the only sterols detected (Table $3)$. Cholesterol is generally the dominant sterol present in copepods and other Crustacea (Goad 1981), with minor amounts of other sterols reflecting the contribution of varied dietary sources (e.g. Harvey et al. 1987).

Copepods fed the ciliate also contained cholesterol as the dominant sterol, with the addition of tetrahymanol and minor amounts of 24-methylcholesta-5,24(28)-dien$3 \beta$-ol and 24-ethylcholesta-5,22-dien-3 $\beta$-ol detected (Table 3). Total sterol concentrations for diatom-fed copepods were $18.1 \pm 3.7 \mathrm{ng}$ animal ${ }^{-1}$ compared to $12.0 \pm 0.4$ $\mathrm{ng}$ for ciliate-fed and $8.1 \pm 1.8 \mathrm{ng}$ for starved copepods (Fig. 2). Ciliate-fed copepods contained $0.7 \mathrm{ng}$ tetrahymanol animal ${ }^{-1}$, which was the most abundant neutral compound aside from cholesterol (Table 3 ). As previously mentioned, Pleuronema sp. synthesizes tetrahymanol de novo and does not contain sterols unless they are supplied exogenously (Harvey and McManus 1991). The decrease in sterol content of copepods fed ciliates compared to those fed diatoms is likely due to the absence of sterols in ciliates for copepods assimilation. After only $96 \mathrm{~h}$, it appeared that the copepods began to substitute sterols absent in their ciliate diet with tetrahymanol.

Eggs produced on the diatom diet contained $0.18 \pm 0.01$ ng total sterol egg ${ }^{-1}$ compared to $0.11 \pm 0.03 \mathrm{ng}$ in eggs from the ciliate diet (Fig. 2). The higher sterol content of eggs from the diatom-fed adults is a likely consequence of copepods consuming sterol-rich algae compared to sterol-poor ciliates. Cholesterol was the major sterol in eggs produced on the algal diet, with 24-methylcholesta$5,24(28)$-dien-3 $\beta$-ol and 24-ethylcholesta-5,22-dien-3 $\beta$ ol (Table 3). Copepod eggs produced on the ciliate diet contained $0.04 \pm 0.02 \mathrm{ng}$ tetrahymanol $\mathrm{egg}^{-1}$, accounting for $35.4 \%$ of the neutral lipid fraction, with cholesterol as the only sterol (Fig. 2).

Triacylglycerol content of copepods-Copepods fed the diatom diet were substantially higher in triacylglycerols than the field-collected, ciliate-fed, or starved copepods (Fig. 3). Diatom-fed copepods contained $121 \pm 23$ ng an- 


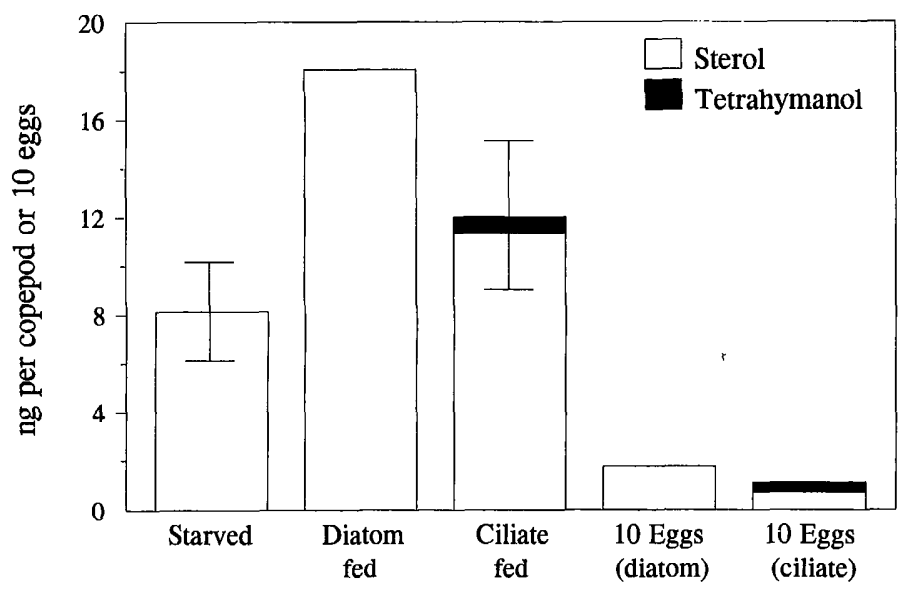

Fig. 2. Concentration of total sterols and tetrahymanol in experimental copepods and eggs produced during each incubation. Error bars are shown only for samples with standard errors $>1.0 \%$ of the mean.

imal $^{-1}$ triacylglycerol, over threefold that observed in field-collected animals (34.5 $\pm 1.1 \mathrm{ng}$ animal $\left.{ }^{-1}\right)$ and over 15 -fold that seen in ciliate-fed copepods $(7.7 \pm 3.9 \mathrm{ng}$ animal $^{-1}$ )(Fig. 3). No triacylglycerol was detected in starved animals.

\section{Discussion}

Feeding and reproduction of $A$. tonsa are governed by the quality and abundance of available foods, with size, shape, species, and biochemical composition all being important aspects of food quality (Cahoon 1981; Houde and Roman 1987; Støttrup and Jensen 1990). In the sense of supporting egg production, the ciliate appeared to be a lower quality food than the diatom, as egg production was 10 -fold lower for ciliate-fed copepods (Table 2). The ciliate did not contain measurable amounts of the polyunsaturated fatty acids $20: 5$ or $22: 6$, which have been suggested as essential fatty acids for growth and development of marine animals (Enright et al. 1986). T. weissflogii contained significant amounts of the 20:5 acid and none of the 22:6 acid, yet egg production was good. Our observation of continued egg production on diatoms containing the 20:5 fatty acid only suggests $A$. tonsa may not have as stringent a dietary requirement for multiple PUFAs as previously hypothesized (Støttrup and Jensen 1990).

Perhaps the most interesting observation from the detailed fatty acid analysis is that copepods and eggs produced from the ciliate diet, and to a lesser degree from the diatom diet, contained fatty acids of bacterial origin. In contrast to copepods and other eucaryotes that synthesize almost exclusively even-chain acids (Fulco 1983; Schweizer 1989), bacteria may synthesize odd-chain length and branched fatty acids (Kaneda 1991). The straight chain $15: 0$ and iso branched $15: 0$ and $17: 0$ acids were present only in small amounts in diatom-fed copepods and were three-fold higher in ciliate-fed copepods. The increased abundance of bacterially derived fatty acids in

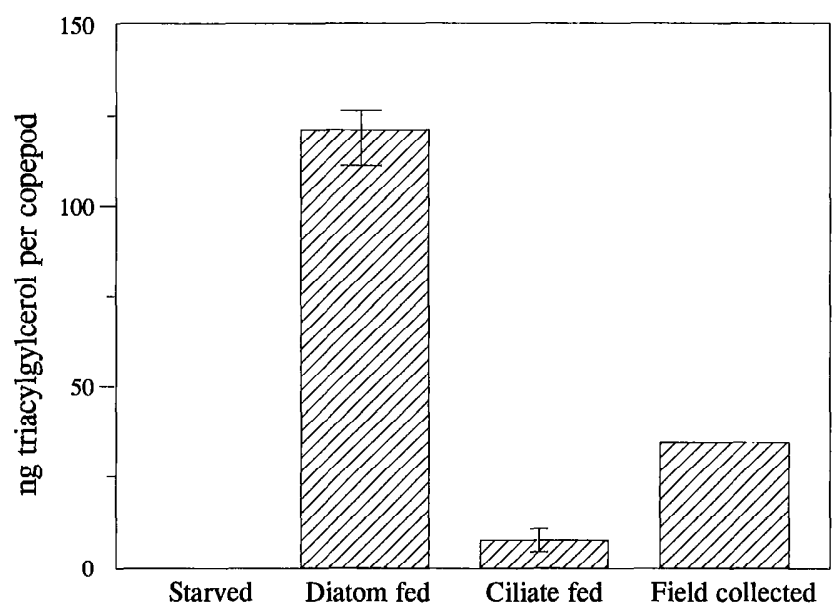

Fig. 3. Concentration of triacylglycerol for field-collected and experimental copepods. Standard errors are shown only for triplicate samples $>2.0 \%$ of the mean.

ciliate-fed copepods suggests that lipids of bacterial origin can be transferred up the food web without modification to copepods that consume protozoa. Once assimilation efficiencies are understood, the contribution of fatty acids from bacteria to the fatty acid composition of copepod populations in the field may be quantified.

In addition to fatty acids, sterol availability may influence survival and egg production in $A$. tonsa. It has been well established that the Crustacea must obtain sterols from their diet because they lack the biosynthetic capacity for de novo synthesis (Goad 1981). Consequently, the copepod must rely on dietary sterols to meet its metabolic requirements, although some selectivity for sterol modification after ingestion has been observed in the calanoid Calanus helgolandicus (Harvey et al. 1987). The sterol distribution of field-collected copepods (Table 3) indicates these animals were primarily feeding on an algal diet with diatoms an important component based on the presence of 24-methylcholesta-5,24(28)-dien-3 $\beta$-ol, a common sterol in diatoms, particularly the Thalassiosira genus (Volkman 1986). The absence of sterols in the ciliate diet and the lack of biosynthetic capacity in $A$. tonsa is reflected in the sterol content of the ciliate-fed copepods, which declined over $60 \%$, from 20.4 to $8.1 \mathrm{ng}$ sterol copepod $^{-1}$ during the experiment (Fig. 2). Compared to their distribution at time zero (i.e. field-collected animals), ciliate-fed and starved copepods also show a general loss in algal sterols (Table 3). It appears that without a continual dietary source of these sterols, they are rapidly lost, with cholesterol remaining as the dominant sterol.

As a conservative component of cell membranes in eucaryotes, a minimum concentration of sterols, whether cholesterol or related structures, is required for maintenance of cellular architecture and membrane function (Gennis 1989). A severe shortage of sterols in the diet might also interfere with steroid metabolism, affecting levels of sex hormones and possibly fecundity (O'Hara et al. 1978). Unless the copepod could sequester the ciliatederived triterpenoid alcohol as a substitute for cholester- 
ol, cellular function would ultimately be compromised as cholesterol is depleted during egg production. The appearance of tetrahymanol in adult copepods and eggs when the adults feed on Pleuronema sp. could be the result of either active uptake or passive assimilation during digestion, and whether tetrahymanol can provide functional equivalence for cholesterol over long periods of time is unknown. Although eggs produced on the ciliate diet, which contained significant amounts of tetrahymanol, were viable, we do not know whether further development would be delayed or deterred with tetrahymanol as a significant component. Egg viability does suggest, however, that copepods may be able to use the triterpenoid alcohol from the ciliate to maintain minimal egg production.

Tetrahymanol is synthesized de novo by several species of marine ciliates when they feed on bacteria (Harvey and McManus 1991). Since ciliates can be considered the source of tetrahymanol in estuarine and coastal systems, its appearance in copepods may provide an estimate of ciliate consumption if copepods are unable to metabolize or modify the structure. Harvey and McManus (1991) found a strong correlation between bacterivorous ciliate biomass and tetrahymanol concentration in laboratory ciliate cultures and field collections, suggesting that tetrahymanol may provide a useful chemical marker of bacterivorous ciliate consumption in natural environments once the partitioning between ingestion, egg production, and feces is known. Based on clearance rates in this study, we estimate that tetrahymanol concentration in adult copepods and eggs accounted for $21.7 \pm 4.1 \%$ of the total tetrahymanol consumed through ciliate ingestion in our experiment. It remains unknown whether the remaining tetrahymanol was metabolized or excreted after copepod ingestion, and the digestion or metabolism of saturated triterpenoid alcohols such as tetrahymanol has not been investigated. Ring-saturated sterols are not altered during passage through the gut of the copepod $\mathrm{Cal}$ anus (Harvey et al. 1989), and by analogy we would predict a similar fate for tetrahymanol. The absence of modified but related structures in copepods or their eggs suggests that if tetrahymanol is structurally altered, it is not retained by the animal. If tetrahymanol were extensively metabolized to render water-soluble products, however, they would not be observed by the methods applied.

Although eggs produced from copepods fed the ciliate diet contained lower sterol concentrations than eggs produced from the diatom diet, eggs from ciliate-fed copepods were higher in total fatty acids. Because hatch success was similar for eggs regardless of diet, it appears that a wide range of fatty acid and sterol content is adequate for egg viability. The absence of PUFAs in eggs produced from ciliate-fed copepods indicates that these fatty acids are not essential for hatching. The amount of sterols present in adults and eggs fed the two diets suggests decreased cholesterol levels may limit egg production in copepods which consumed ciliates.

Among the lipids, triacylglycerols provide short-term energy storage and are rapidly used by copepods during starvation (Lee et al. 1974; Sargent et al. 1977). Copepods fed the ciliate diet in our experiment maintained mod- erate triacylglycerol concentrations, whereas starved animals did not. The diatom-fed copepods were highest in triacylglycerols, suggesting that $T$. weissflogii is a better diet than Pleuronema sp. in terms of providing $A$. tonsa with higher concentrations of energy stores. Whereas the ciliate may supply the copepod with a source of fatty acids adequate to support survival and maintain some egg production, it is clearly an incomplete source of lipids for growth and reproduction. In nature, food probably never consists of a single ciliate or algal species, and $A$. tonsa feeding on a mixture of Pleuronema sp. and T. weissflogii would have an ample supply of both sterols and fatty acids for triacylglycerol synthesis.

The lipid content of copepods appears as variable as their food, and there is a need for more information on how survivorship and fecundity are affected by this variability. The best food situation for copepods is probably a microphytoplankton bloom or a copious population of herbivorous ciliates, but in estuaries and coastal waters with high detrital loads, other ciliates may dominate (Gifford and Dagg 1988; Dolan 1991). Our observation that a bacterivorous ciliate may support egg production for a short period of time is important in a system where bacterivorous ciliates represent the most likely link for the direct transfer of bacterial carbon into the metazoan food web. Eggs containing the ciliate lipid tetrahymanol were able to hatch, and additional information is needed on the possible effects of tetrahymanol on further growth and development of nauplii. The use of bacterial and ciliatespecific lipids may prove an important measure of trophic interactions in estuarine food webs once measures of the assimilation and biochemical fate of these lipids are known.

\section{References}

Berggreen, U., B. Hansen, AND T. Kiørboe. 1988. Food size spectra, ingestion and growth of the copepod Acartia tonsa during development: Implications for determination of copepod production. Mar. Biol. 99: 341-352.

CAHOON, L. B. 1981. Reproductive response of Acartia tonsa to variations in food ration and quality. Deep-Sea Res. 28: 1215-1221.

Canuel, E., AND C. S. Martens. 1992. Seasonal variations in the sources and alteration of organic matter associated with recently-deposited sediments. Org. Geochem. 20: 563578.

Capriulo, G. M., ANd E. J. Carpenter. 1983. Abundance, species composition and feeding impact of tintinnid microzooplankton in central Long Island Sound. Mar. Ecol. Prog. Ser. 10: 277-288.

DolAN, J. R. 1991. Microphagous ciliates in mesohaline Chesapeake Bay waters: Estimates of growth rates and consumption by copepods. Mar. Biol. 111: 303-309.

Dunstan, G. A., J. K. VOlKman, S. M. BARRetT, J.-M. Leroi, AND S. W. JEFFREY. 1994. Essential polyunsaturated fatty acids from 14 species of diatom (Bacillariophyceae). Phytochemistry 35: 155-161.

Enright, C. T., G. F. Newkirk, J. S. Craigie, AND J. D. Castell. 1986. Evaluation of phytoplankton as diets for juvenile Ostrea edulis L. J. Exp. Mar. Biol. Ecol. 96: 1-13.

Frost, B. W. 1972. Effects of size and concentration of food particles on the feeding behavior of the marine planktonic 
copepod Calanus pacificus. Limnol. Oceanogr. 17: 805815.

Fulco, A. J. 1983. Fatty acid metabolism in bacteria. Prog. Lipid Res. 22: 133-160.

GENNIS, R. B. 1989. Biomembranes: Molecular structure and function. Springer.

GIFFORD, D. J. 1988. Impact of grazing by microzooplankton in the Northwest Arm of Halifax Harbour, Nova Scotia. Mar. Ecol. Prog. Ser. 47: 249-258.

- 1991. The protozoan-metazoan trophic link in pelagic ecosystems. J. Protozool. 38: 81-86.

- AND M. J. DAGG. 1988. Feeding of the estuarine copepod Acartia tonsa Dana: Carnivory vs. herbivory in natural microplankton assemblages. Bull. Mar. Sci. 43: 458468.

GoAD, L. J. 1981. Sterol biosynthesis and metabolism in marine invertebrates. Pure and Appl. Chem. 51: 837-852.

Goulden, C. E., AND A. R. Place. 1990. Fatty acid synthesis and accumulation rates in daphniids. J. Exp. Zool. 256: $158-178$.

Harvey, H. R., G. Eglinton, S. C. M. O'Hara, and E. D. S. CORNER. 1987. Biotransformation and assimilation of dietary lipids by Calanus feeding on a dinoflagellate. Geochim. Cosmochim. Acta 51: 3031-3040.

- S. C. M. O'Hara, G. Eglinton, AND E. D. S. Corner. 1989. The comparative fate of dinosterol and cholesterol in copepod feeding: Implications for a conservative molecular biomarker in the marine water column. Org. Geochem. 14: 635-641.

HARvey, R. R., AND G. B. McManus. 1991. Marine ciliates as a widespread source of tetrahymanol and hopan- $3 \beta$-ol in sediments. Geochem. Cosmochim. Acta 55: 3387-3390.

Hollibaugh, J. T., J. A. Furham, and F. AzAm. 1980. Radioactively labeling of natural assemblages of bacterioplankton for use in trophic studies. Limnol. Oceanogr. 25: 172-181.

Houde, S. E. L., AND M. R. Roman. 1987. Effects of food quality on the functional ingestion response of the copepod Acartia tonsa. Mar. Ecol. Prog. Ser. 40: 69-77.

Johns, R. B., G. J. Perry, AND K. S. JACKSON. 1977. Contribution of bacterial lipids to recent marine sediments. Estuarine Coastal Mar. Sci. 5: 521-529.

KANEDA, T. 1991. Iso- and anteiso-fatty acids in bacteria: Biosynthesis, function, and taxonomic significance. Microbiol. Rev. 55: 288-302.

Lee, R. F., J. C. Nevenzel, AND A. G. Lewis. 1974. Lipid changes during life cycle of marine copepod, Euchaeta japonica Marukawa. Lipids 9: 891-898.

LONSDALE, D. J. 1979. Carnivorous feeding behavior of the adult calanoid copepod Acartia tonsa Dana. J. Exp. Mar. Biol. Ecol. 36: 235-248.

Nichols, P. D., J. K. Volkman, AND R. B. Johns. 1983. Sterols and fatty acids of the marine unicellular alga, FCRG 51. Phytochemistry 22: 1447-1452.

NotT, J. A., E. D. S. Corner, L. J. MAvin, ANd S. C. M. O'HARA. 1985. Cyclical contributions of the digestive epithelium to faecal pellet formation by the copepod Calanus helgolandicus. Mar. Biol. 89: 271-279.

O'Hara, S. C. M., E. D. S. CoRner, And C. C. Kilvington. 1978. On the nutrition and metabolism of zooplankton. 12. Measurements by radio immunoassay of the levels of a steroid in Calanus. J. Mar. Biol. Assoc. U.K. 58: 597605.

Perry, G. J., J. K. Volkman, R. B. Johns, AND H. J. Bavor, $J_{R}$. 1979. Fatty acids of bacterial origin in contemporary marine sediments. Geochim. Cosmochim. Acta 43: 17151725 .
Pierce, R. W., AND J. T. Turner. 1992. Ecology of planktonic ciliates in marine food webs. Rev. Aquat. Sci. 6: 139-181.

Prahl, F. G., G. Eglinton, E. D. S. Corner, S. C. M. O'HARA, AND T. E. V. ForsBerg. 1984. Changes in plant lipids during passage through the gut of Calanus. J. Mar. Biol. Assoc. U.K. 64: 317-334.

Roman, M. R. 1984. Utilization of detritus by the copepod Acartia tonsa. Limnol. Oceanogr. 29: 949-959.

SANDERS, R. W., AND S. A. WickhaM. 1993. Planktonic protozoa and metazoa: Predation, food quality and population control. Mar. Microb. Food Webs 7: 197-223.

SARGENT, J. R., AND S. FALK-PETERSEN. 1988. The lipid chemistry of calanoid copepods. Hydrobiologia 167/168: 101114.

, R. R. Gatten, E. D. S. CORner, and C. C. Kilvington. 1977. On the nutrition and metabolism of zooplankton. J. Mar. Biol. Assoc. U.K. 57: 525-533.

SCHWEIZER, E. 1989. Biosynthesis of fatty acids and related compounds, p. 3-50. In C. Ratledge and S. G. Wilkerson [eds.], Microbial lipids. Academic.

SHerR, B. F., E. B. SHERr, AND R. D. FAllon. 1987. Use of monodispersed, fluorescently labeled bacteria to estimate in situ protozoan bacterivory. Appl. Environ. Microbiol. 53: $958-965$.

SHERR, E. B., AND B. F. SHERR. 1987. High rates of consumption of bacteria by pelagic ciliates. Nature 325: 710 711.

, R. D. Fallon, AND S. Y. Newell. 1986. Small, aloricate ciliates as a major component of the marine heterotrophic nanoplankton. Limnol. Oceanogr. 31: 177-183.

Stoecker, D. K., AND J. M. CAppuzzo. 1990. Predation on protozoa, its importance to zooplankton. J. Plankton Res. 12: 891-908.

StøtTRUP, J. G., AND J. JENSEN. 1990. Influence of algal diet on feeding and egg-production of the calanoid copepod Acartia tonsa Dana. J. Exp. Mar. Biol. Ecol. 141: 87-105.

Ten Haven, H. L., M. Rohmer, J. Rullkötter, AND P. BisSERET. 1989. Tetrahymanol, the most likely precursor of gammacerane, occurs ubiquitously in marine sediments. Geochim. Cosmochim. Acta 53: 3073-3079.

Tester, P. A., AND J. T. TURner. 1990. How long does it take copepods to make eggs? J. Exp. Mar. Biol. Ecol. 141: 169182.

VOLKMAN, J. K. 1986. A review of sterol markers for marine and terrigenous organic matter. Org. Geochem. 9: 83-99. , D. A. EveritT, AND D. I. Allen. 1986. Some analyses of lipid classes in marine organisms, sediments and seawater using thin-layer chromatography-flame ionization detection. J. Chromatogr. 356: 147-162.

- - S. W. JefFrey, P. D. Nichols, G. I. Rogers, AND C. D. GaRland. 1989. Fatty acid and lipid composition of 10 species of microalgae used in mariculture. J. Exp. Mar. Biol. Ecol. 128: 219-240.

White, J. R., AND M. R. Roman. 1992. Seasonal study of grazing by metazoan zooplankton in the mesohaline Chesapeake Bay. Mar. Ecol. Prog. Ser. 86: 251-261.

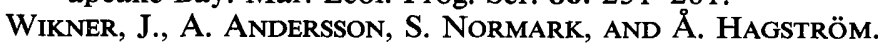
1986. Use of genetically marked minicells as a probe in measurement of predation on bacteria in aquatic environments. Appl. Environ. Microbiol. 52: 4-8.

Submitted: 8 July 1994 Accepted: 1 February 1995 Amended: 8 March 1995 